\title{
Regionalization, Pan-Asian Relations, and the Middle East
}

\author{
Anoushiravan Ehteshami ${ }^{1}$
}

Published online: 26 April 2015

(C) The Author(s) 2015. This article is published with open access at Springerlink.com

\begin{abstract}
Research on the emerging links between the Middle East (West Asia) and other parts of Asia has grown considerably since late twentieth century. Indeed, the contributions to this special edition of the journal reflect some of the pioneering work taking place on pan-Asian relations encompassing new analysis of the Middle East's links with the 'East' - Central, South, and East Asia. The research in this field, looking back into history as well as forward, has grown in response to the changing dynamics of intra-Asian relations following the end of the Cold War in 1990 and the collapse of the Soviet Union as a Eurasian land empire just a year later. The end of bipolarity encouraged new transnational relations and further regionalization of a new world order. As multi-polarity has steadily given way to a state of non-polarity, so the veil has also been lifted on the significant economic and political ties which have grown across strategic regions. In considering strategic regions, it is contended here that Asia is home to the most dynamic of these, in terms of asset accumulation, geopolitical weight, population size, and economic prowess. But it is also significant for the volatility which appears along the fault lines of historical animosity, national security tensions, modern-day rivalries, border and resources disputes, and the strengthening of communalism and divisive role of identity politics. Moreover, the collapse of the Soviet control of much of Central Asia opened up new spaces for exchange in Asia, much encouraged by the exploitation of hydrocarbon reserves of the Soviet successor states in Asia (also Azerbaijan in the Caucasus). But, pan-Asian ties predate the post-Cold War
\end{abstract}

\footnotetext{
These papers were brought forward and taken through an extensive review process from a wider body of work arising from several major research projects that I myself have been leading since 2006 on what I have called the Asianization of the Middle East through the generous support of UK research funding councils, most notably from the Economic and Social Research Council (ESRC), the Arts and Humanities Research Council (AHRC), and also the British Academy and the Higher Education Funding Councils in England and Scotland. Since 2011, the research on 'Asianization', including new work on the making of the New Silk Road, has also benefited from the support of the al-Sabah Programme at Durham University, UK.
}

Anoushiravan Ehteshami

a.ehteshami@durham.ac.uk

1 Durham, UK 
transformations of the global system, and several Asian powers were able to negotiate mutually beneficial links soon after the Second World War. Although evidence of ancient pan-Asian relations is to be found in the Silk Road, systemic shift in our time is clearly leading to a perceptible transfer of the global economic balance Eastwards, which has brought with it the rise of energy-hungry Asian economies in the twenty-first century. Asian demand for energy has changed the complexion of Middle East-Asia relations, and pan-Asian relations in this context are today a reflection of the changing contours of the global political economy.

Keywords Regionalization · Pan-Asian relations · West Asia - MENA subsystem · Energy

\section{Introduction}

The discussion in this volume reflects the many interesting debates which have been taking place in Durham and elsewhere ${ }^{1}$ since the mid-2000s on how inter-Asian, panAsian, relations are being shaped and indeed being mediated. ${ }^{2}$ Scholarship has grown considerably on this emerging relationship - this emerging 'nexus' [11] - and is increasingly reflecting the diverse perspectives of the many parties involved [21]. When considered in terms of trade and investment partnerships, political and security links, and also cultural and social relationships, evidence points to a broadening and deepening of pan-Asian exchanges [18]. The underlying thesis of this paper, then, is that while there is a steady global Eastward shift of industry and economic dynamism, the most dramatic and often neglected aspect of this global shift is its impact on global regions. One such region which has been directly affected by systemic shift is the Middle East and North Africa region, specifically the 'West Asia' part of it [6]. ${ }^{3}$ It is also argued that the end of the Cold War removed the barrier to regionalization [12]. Indeed, arguably, regions since the end of the Cold War have come to underpin the globalization of the international system [22].

Secondly, rapid industrialization of China and India has increased the propensity for Asianization as it has raised the demand for hydrocarbons from the emerging Asian economies - just as it was flattening in Europe and North America. Asia, as will be shown below, has become the key market for hydrocarbon exports. Thirdly, as higher oil prices facilitated a faster rate of capital accumulation in the Middle East and North Africa (MENA) oil-exporting countries, so they, particularly the richest Gulf

\footnotetext{
${ }^{1}$ The Gulf Research Center has actively followed the trends since 2006, the annual Gulf Research Meeting in Cambridge (UK) has had a standing workshop on Asia-Gulf relations since 2010, and the Washington-based Middle East Institute launched a vibrant Middle East-Asia Project in 2012.

${ }^{2}$ Our first international workshop on 'The Emerging East Asia-Middle East Nexus' in 2009 was followed a major conference in Durham on 'The Historical Legacy of Asianization' (February 2013). We then held a joint conference with the Middle East Technical University in Ankara on 'The Asianization of the Middle East' (June 2013), an international conference in Durham in April 2014 with Kuwait University on 'Pan-Asian Relations and the Middle East', and since June 2014 have been developing a joint project on China and the Middle East with Nottingham University's School of Contemporary Chinese Studies, and a further research partnership on the 'New Silk Road' with the Abu Dhabi-based Center for East Asian Studies and Research. ${ }^{3}$ West Asia also maps nicely onto the Persian Gulf subregion of the MENA subsystem. The Persian Gulf in turn exemplifies the most globalized and economically dynamic part of the MENA region.
} 
Cooperation Council (GCC) countries with accumulated surpluses and sovereign wealth funds exceeding $\$ 1.7$ trillion, ${ }^{4}$ have raised their volume of imports from industrializing Asia and are also increasing their investments in the emerging Asian economies. As a result, both sides are building networks and from these networks are arguably emerging shared visions, if not interests.

Fourthly, although the transition from bipolarity to unipolarity in the 1990s enabled the USA to pursue its national interest with little concern about a backlash-China and India were still 'emerging', Japan was already a close Asian ally, Russia was weak and in apparent decline, and Europe was engrossed in continental rebuilding-regional powers responded in different ways to the US unipolar moment: some drew closer still to the USA and bandwagoned with it, while others choose to stand apart and distance themselves from the remaining superpower. In the latter case, such regional actors were then either coopted (Libya, Vietnam) or were isolated (Iran, Iraq, Sudan). The bombing of targets in Iraq and Sudan was a consequence of this, as was the isolation of Iran in the 'dual containment' belt the USA put around both Iran and Iraq in the 1990s. But the US 'new world order' proved to be short-lived, and the unipolarity of the 1990s swiftly gave way to a multi-polar structure in the 2000s in which the USA had to contend with the voice of an expanded European Union in international fora and the concerns of the emerging Asian and Latin American powers. The sense of concern following its defence strategy of the 'war on terror', which not only argued for US intervention in other countries but also justified the extrajudicial extraction of suspects from third countries, was compounded by the devastating war in Iraq in 2003, which effectively changed the Middle East regional balance of power. Additionally, the depletion of US treasure (to the tune of $\$ 1$ trillion) and the resistance to its unilaterality did much to expose it to pressure, while facilitating the resurrection of regional and major powers. By the mid-2000s, Russia appeared to be standing on its own two diplomatic and security feet, and China and India were already making diplomatic inroads in regionsAfrica and Latin America in the case of China [14] and the Middle East and Central Asia in the case of India [5] — hitherto inaccessible to them. The transition from multipolarity to non-polarity, however, was quicker still, and following the 2008 financial crisis, during which the Atlantic economies lost much ground to the emerging economies, they found themselves vulnerable to the policies of altogether new actors, the most prominent of which was the BRICS. ${ }^{5}$ I believe that regional actors, and the international system more broadly, are still coming to terms with the realities of a nonpolar world in which no one power can dictate terms of engagement. On the one hand, global non-polarity provided the conditions for the birth of such partnerships as the BRICS, but on the other hand, non-polarity also piqued the interest of counterhegemonic powers. The few such regional powers, with resources or geopolitical advantage, stepped up their interventions in their respective regions in an effort to shape their neighbourhood to their own interests. Counter-hegemons, thus, have tended to act where the USA has had a greater interest, as in the Middle East and East Asia. Regional powers more generally have done the same, and ironically, the USA has had to step up its regional interventions precisely because other powers have come to challenge its role and influence. Thus, while it has tried to assume a 'pivot' to East Asia

\footnotetext{
${ }^{4}$ Latest data from http://www.bqdoha.com/

${ }^{5}$ Brazil, Russia, India, China, and South Africa
} 
and build closer links with India and its other Asian allies, it at the same time has had to service its alliance structures in the Middle East (showing a strong presence in West Asia and reinforcing its security commitment to its traditional allies), and also remaining fully engaged with the multiple crises of the MENA subsystem. Non-polarity has raised the US regional profile and not diminished it.

So, what are the drivers of the growing interdependence, so-called complex interdependence, ${ }^{6}$ between the edges of the Asian continent and the broader implications of this new Asian 'convergence' for the structure of the international system? Its drivers, I would suggest, are, firstly, systemic shift, which is encouraging convergence; secondly, the restructuring of international relations in a world of regions; and thirdly, reinforcing trade compatibility (hydrocarbons for East and South Asia in exchange for required goods and services) providing fuel for the convergence. What this means for the broader workings of the international system is harder to judge, but what it does show of the international system is that globalization is increasingly Asianization of the international system in which the relative balance of power has changed sufficiently to cause an Eastward shift. Furthermore, as systemic shift is changing the hierarchy of the international system, it is also placing greater emphasis on the role and regional importance of emerging Asian powers. In this, it is deepening the regionalization of Asia.

\section{Regions and Asian Realities}

With the vertical and horizontal growth of the European Union, as an exemplar of regional integration; the rapid globalization of production chains and means of exchange; and of course the consolidation of regionalist trends in Asia, Africa, and Latin America, regionalism as a rich field of enquiry has grown in importance and relevance over the last 20 years [12, 22]. Efforts at conceptualizing (state-led and state-orchestrated) regionalism have provided many insightful reflections on how, where, and why regional integration may have accelerated in recent decades [13]. Within this discussion, we also see broader reflections on other forces at play, namely the process of globalization $^{7}$ and with it that of regionalization, ${ }^{8}$ as the dominant forces changing and shaping international relations. If conceived as a system, however, then the fact remains that globalization generates structural problems associated with its uneven spread and as such inevitably encourages further vertical stratification of the international system. Where countries are in this vertically stratified international system is increasingly determined by the regional institutions and structures surrounding them, and

\footnotetext{
${ }^{6}$ This concept provided the analytical basis of the discussion in Ehteshami and Miyagi [11].

${ }^{7}$ As the concept of globalization has a mixed disciplinary heritage, no single definition can encompass its complexity of meaning, and certainly, dispute continues to rage over it being considered a process [7] or new system [23] — whether it is the endgame or a stepping stone. There is consensus however that it challenges the state system and its place as the only and the one dominant form of cross-border exchange, and in this sense, I will conceive of globalization in this article as a three-pronged phenomenon, which shortens distance and squeezes space, stretches human activity (economic, political, and social) beyond national frontiers, and deepens and increases the density of global interaction (interconnectedness).

${ }^{8}$ Hurrell has defined this as 'the growth of societal integration within a region and... the often undirected processes of social and economic interaction' ([16], p. 39). In my case, I include both state and commercial actors as regionalizers.
} 
regionalism can arguably break down the territorial barriers to integration [20]. Thus, the strengthening of regionalism could turn it into 'a building block of an intrusive world order [and] new forms of regional identity built around intrusive regionalism' and ultimately an 'important stepping stone to a post-Westphalian world order' ([1], p. 30).

But regionalism provides only some protection, as we have seen in the case of the vulnerable Eurozone countries in the EU, and even such 'tight regions' do not fully shield their members from the vagaries of global upheavals. However, in the absence of tight regionalism, it is in fact informal networks ('loose regionalization') which can best characterize cross-region interactions and perhaps this is nowhere more evident than in the emerging pan-Asian networks. By way of comparisons, pan-Asian networks are weaker than regional-based groupings: so, the ASEAN Forum, for example, is more formalized than any East Asia-West Asia network. Indeed, even the emerging intercontinental networks, namely the 12-member Trans-Pacific Partnership (TPP) and the EU-US Transatlantic Trade and Investment Partnership (TTIP), offer a more structured dialogue than any inter-Asian equivalent. The closest to an Asian forum is the sixmember Shanghai Cooperation Organization (SCO), which has identified such regional powers as Iran, India, and Pakistan (and also Mongolia) as eligible for membership. If the SCO does grow to 10 members, then Russia would be its only 'European' member and together the 10 countries will account for $20 \%$ of the world's GDP (at current prices), $43 \%$ of the world's population, and over $25 \%$ of its natural gas reserves (the fuel of choice in the coming years).

The second point to make is that while regionalization theory informs the conceptual framework of this analysis, pan-Asianization as a feature of Asian regionalization remains patchy and uneven: in reality, only some MENA states are 'Asianizing', and by the same token, it has been the more sophisticated Asian economies which have deepened their Middle East (West Asian) networks. So, regionalization-mirroring globalization - is neither an even nor a uniform process. But to make matters more complex, even the idea of Asia remains contested; at best, Asia is an amalgam of diverse countries and of unequal and uneven powers, and of contested histories. Regionalism, though prevalent, is fractured in Asia. In Asia, regions can usefully be divided into two distinct realms: Pacific Asia and South and Central Asia. The former, encompassing East Asia, has complex roots in post-War distribution of power between key East Asian countries and can itself be divided into two dynamic subregions of Southeast Asia and Northeast Asia.

South and Central Asia, on the other hand, are relative new comers to regionalism. South Asia was firmly a piece of the global competition between the two superpowers but has also had a micro-cold war of its own fuelled by intense hostility between India and Pakistan. Thus, regionalism in South Asia only began to take shape in the 1980s, and it was not until 1985 that the eight-member South Asian Association for Regional Cooperation (SAARC) was born. ${ }^{9}$ Central Asia of course was firmly under Soviet control and West Asia was in large part pro-Western. ${ }^{10}$ Central Asia is now cocooned in the regional bodies of SCO and ECO.

\footnotetext{
${ }^{9}$ With $21 \%$ of the world's population and an economy increasingly rivalling that of China and Japan, SAARC has begun to realize the value of closer cooperation as Asian economies have expanded.

${ }^{10}$ Iraq veered towards the Soviet Union after the revolution that overthrew its monarchy in 1958, and Iran's Islamist revolutionaries adopted a policy of 'neither East nor West' after the overthrow of the monarchy in that country in 1979.
} 
For much of the twentieth century, Asian regions were subject to superpower pressures, and despite efforts of some, such as the subregional organization of ASEA $\mathrm{N}$, to break free of geopolitical pressures, regional relations remained hostage to great power politics. Indeed, the character of the dominant outside power's presence, the USA, in Pacific Asia is defined by the post-War security conditions of the region. US troops remain on Japanese and Korean soil and protect Taiwan, military forces exercise with almost all 10 ASEAN countries, and the US Seventh Fleet (with 60+ surface vessels and nuclear submarines, 300 aircraft, and 40,000 troops) patrols the Yellow, South China, and East China seas; the Sea of Japan; the Malacca Strait; as well as the Indian Ocean.

Asia, therefore, is a penetrated region. It is also a continent of unequal and competing powers and a cauldron of unresolved grievances. It is beset by the SinoJapanese rivalry, Pyongyang's nuclear weapons programme, and rising Sino-US maritime tensions, all of which are adding to the region's insecurity and also to the militarization of an already militarized region. ${ }^{11}$

The Middle East and North Africa regional system is equally dynamic but even more volatile. The MENA region is beset by conflict; wars between Arab states and non-state actors and Israel have been a feature of the region for decades, and three inter-state wars in the Persian Gulf since 1980 have done much to shape inter-state relations of this strategically important subregion. Furthermore, revolutions, uprisings, and coup d'états have shaped the domestic form of states since the 1950s [4]. Yet, here are located some of the oldest regional organizations of the modern period: the 10-member Economic Cooperation Organization (successor to the three-member Regional Cooperation for Development founded in 1964) is the largest non-Arab Muslim regional body in the world, and the League of Arab States (AL), established in 1945 with just six members, is perhaps the best known of MENA's regional organizations, but the chequered history of this 22-member body tells the story of the MENA subsystem's dysfunctionality and structural tensions. The League's inability to stamp its own authority on the regional system, regularize MENA inter-state relations, create a common platform for the protection of the interests of its members, advance development, or act as a fully fledged regional organization at the global level underlines the instability of the MENA region. Arab states have gone to war against each other, disowned and undermined each other in public fora, and as a consequence torn at the pillars around which the League could have built a central axis for the Arab states in the regional system. ${ }^{12}$ Inter-state competition as a key feature of the MENA regional system has partly been to blame for this state of affairs, compounded as it has been by external intervention. But since the 1990s, it has been state implosion which has shaken the regional system [8]. Since 2011 in particular,

\footnotetext{
${ }^{11}$ North Korea's nuclear programme and its belligerence unsettle its southern neighbour and also Japan, and China's military assertiveness since 2010 partly explains the heightened sense of insecurity in East Asia, which is not helped by rising defence budgets. China's defence budget since the early 2000s has grown 30 times and stood at $\$ 132$ billion in 2014, up $12.2 \%$ on 2013, which is enabling the PLA to modernize and compete more effectively with the forces of its neighbours; Japan's 2015 military budget is the country's largest, at a record $\$ 42$ billion, and will enable the Japanese Self-Defence Force to modernize and add a further 30 amphibious vehicles, six F-35A stealth fighters, and unmanned aircraft to its arsenal (see The Economist, 15 March 2014, and 19 January 2015).

${ }^{12}$ Egypt's expulsion from the League for its unilateral peace treaty with Israel in 1979, Iraq's censure for invading neighbouring Kuwait in 1990, and Syrian regime expulsion from the League in 2012 serve as examples of inter-Arab conflicts.
} 
several Arab regimes - Iraq, Libya, Syria, and Yemen - have lost central control of their territories and become victims of powerful non-state Islamist actors; Egypt, the geopolitical and cultural cornerstone of the Arab order, has been weakened by years of internal turmoil; and smaller Bahrain, Jordan, and Tunisia have been subject to much domestic upheaval. In this chaos, formerly strong states have been reduced to rubble and some small states have become influential regional actors. In this regional system, power remains fluid and is no longer defined by the traditional measures (of territory, population, or size of armed forces). Thus, the United Arab Emirates (with just 1.2 million Emiratis) has acquired more penetrative power than Egypt (with 82 million). ${ }^{13}$ Also, legitimacy is heavily contested within and across Arab state boundaries. Furthermore, the region's powerful actors-Iran, Israel, Saudi Arabia, and Turkey-are divided amongst themselves and are pursuing maximalist aims often at the expense of each other and the wider regional order. MENA is a regional order defined by anarchy and profound chaos.

So, neither region - whether East Asia or West Asia - is particularly stable, and despite the regions' respective economic strengths, both remain subject to external power pressures and also inter-state internal rivalries. South and Central Asia, on the other hand, have acquired established - through still competing-power relations, which do not necessarily make these regions more conducive to pan-regionalization but at least make them less prone to open hostility. The nuclear stand-off between India and Pakistan is a major feature of the South Asia subregion, and mutual assured destruction does keep the parties in conversation and alerts Islamabad and New Delhi to keep the level of rivalry to manageable dimensions. Central Asian states, in the meanwhile, are building links with both China and India without alienating Moscow, in the expectation of Asian demand for their hydrocarbons will spur a closer partnership between them and the global economies of this century.

The pivot of Asianization today is China [15], but as Japan started all this, it remains a key actor. Japan's continuing heavy economic weight, its close security relations with the USA (and also growing links with India and South Korea), and its military expansions have raised its standing in intra-Asian relations. Japan remains a key partner of the MENA oil exporters and is a keen exporter of goods and technological services to them. Of course, India plays a major role in the forging of pan-Asian relations and particularly those between the Gulf states and the subcontinent, given its historic relations with the Gulf states. The legacy of its historic ties with West Asia and the prosperity of the expatriate Indians living in the oil-rich Gulf Arab have tended to act as magnets for India. Pakistan too has close links with the Gulf Arab states and not only provides labour for these capital-rich countries but also assists several of them militarily. The natural bond between these subregions is being enhanced by the growing economic links between the Gulf states and the subcontinent.

\section{Energy Drives Relations}

History in the Middle East in the twentieth century was a by-product of Western intervention, a colonial legacy that not only shaped the regional state system but

${ }^{13}$ The UAE's GDP is \$390 billion and Egypt's is around \$272 billion. 
Table 1 World oil consumption patterns, 1965-1995 (mb/d)

\begin{tabular}{lcrrrrrrrrrr}
\hline & 1965 & 1968 & 1971 & 1974 & 1977 & 1980 & 1983 & 1986 & 1990 & 1993 & 1995 \\
\hline China & 0.2 & 0.3 & 0.8 & 1.2 & 1.6 & 1.8 & 1.7 & 2.0 & 2.3 & 3.1 & 3.5 \\
EU6 & 5.8 & 7.6 & 10.0 & 10.1 & 10.4 & 10.7 & 10.4 & 10.0 & 10.1 & 10.1 & 10.5 \\
India & 0.2 & 0.3 & 0.4 & 0.4 & 0.5 & 0.6 & 0.8 & 0.9 & 1.2 & 1.3 & 1.6 \\
Japan & 1.7 & 2.8 & 4.3 & 5.1 & 5.1 & 5.0 & 4.4 & 4.5 & 5.3 & 5.4 & 5.8 \\
RoK & 0.03 & 0.1 & 0.2 & 0.2 & 0.4 & 0.5 & 0.5 & 0.6 & 1.0 & 1.5 & 2.0 \\
USA & 11.5 & 13.4 & 15.2 & 16.6 & 18.4 & 17.1 & 15.2 & 16.3 & 17.0 & 17.2 & 17.7 \\
USSR & 3.3 & 4.1 & 5.1 & 6.6 & 7.4 & 8.4 & 8.3 & 8.4 & 8.4 & 5.8 & 4.5 \\
\hline
\end{tabular}

Calculated from BP, Statistical Review of World Energy. Various annual editions

EU6 France, Germany, Italy, Netherlands, Spain, and UK

also determined the rise and demise of the Middle East's regime types and political elites. For the post-War period the region's abundant hydrocarbon resources and its proximity to the Soviet Union ensured a permanent Western presence in the region, which the USA came to champion from the 1950s. Thus, with the exception of Japan (which joined the ranks of the West's major oilimporting countries in the 1960s and by the 1980s was accounting for over $7 \%$ of world oil consumption) and South Korea in Asia, until the 1980s, much of the region's oil output was destined for the industrialized countries of Europe and the USA. Thus, in the 1970 s, the USA alone was taking some $40 \%$ of its oil imports from the Persian Gulf (West Asia) (Table 1).

Rising demand from emerging economies of China and India, in particular, began to change the picture, given that South Korea's (RoK) consumption plateaued in the 1990s. As Table 2 shows, combined oil consumption of China and India in 1998 was barely greater than that of Japan's, but just a decade later, the two Asian giants were consuming nearly three times more oil than Japan and China's demand alone was outstripping that of Europe's largest economies. To put these figures in a broader context, China's energy profile changed dramatically in the mid-1990s from being a net exporter to a net importer of petroleum, which today has made China the world's second largest consumer of oil. Indeed, BP has estimated that China will be the main source of oil consumption growth in the world in the coming decade, to overtake the USA as the world's greatest consumer of oil with 17.5 million barrels per day consumed by $2030 .{ }^{14}$

Petroleum consumption of India, Japan, and South Korea completes the Asian energy map, which between them consumed over 10 million barrels of oil per day $(\mathrm{mb} / \mathrm{d})$ in 2012. Adding this figure to that of China's, then these four Asian economies make up the world's largest group of consumers, accounting for over 20 million barrels of global output, well exceeding the EU's total of $12.8 \mathrm{mb} / \mathrm{d}$. What this translates into is that as much as half of the Middle East's oil output is now heading to these four countries and also some $70 \%$ of the region's natural gas output is being consumed by

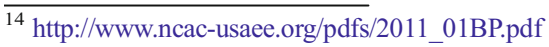


Table 2 World oil consumption patterns, 1998-2012 (mb/d)

\begin{tabular}{lrrrrrrrr}
\hline & 1998 & 2000 & 2002 & 2004 & 2006 & 2008 & 2010 & 2012 \\
\hline China & 4.4 & 4.9 & 5.5 & 7.0 & 10.1 & 10.1 & 9.8 & 10.7 \\
EU6 & 9.9 & 10.9 & 10.8 & 10.9 & 10.8 & 10.0 & 9.7 & 8.3 \\
India & 1.9 & 2.3 & 2.3 & 2.5 & 2.7 & 3.1 & 3.3 & 3.7 \\
Japan & 5.5 & 5.6 & 5.4 & 5.3 & 5.2 & 4.8 & 4.4 & 4.7 \\
RoK & 2.0 & 2.2 & 2.3 & 2.3 & 2.3 & 2.3 & 2.3 & 2.5 \\
Russia & 3.7 & 3.6 & 3.6 & 3.8 & 3.9 & 4.1 & 4.3 & 4.4 \\
USA & 18.9 & 19.7 & 19.8 & 20.1 & 21.0 & 19.5 & 19.2 & 18.5 \\
\hline
\end{tabular}

Calculated from BP, Statistical Review of World Energy. Various annual editions

EU6 France, Germany, Italy, Netherlands, Spain, and UK

them. Put another way, in 2013, $41 \%$ of China's oil imports came from West Asia, $63 \%$ of India's, and as much as $75 \%$ of Japan's [24].

The growing relationship has meant that $67 \%$ of the GCC's exports headed to Asia in 2013, and this group of countries imported $40 \%$ of its needs from Asia. ${ }^{15}$ In the 10 years following 2007, the GCC's imports from China doubled and its imports from India increased by $26 \%$ in the same period [9]. By 2020, China is likely to be this group of countries' biggest export market [2] and annual trade between them could reach $\$ 350$ billion. Looking at India's trade with Iran and Saudi Arabia, we can see that it has grown substantially as well in the 2000s: from $\$ 3.4$ billion with Saudi Arabia and $\$ 1.6$ billion with Iran in 2005 (a total of $\$ 5.0$ billion), it grew to $\$ 34.5$ billion in just 5 years. In the case of South Korea, trade with the region is probably even more significant, with three Middle East states appearing on its list of top 10 importers in 2010.

Yet, this is at best a slowly maturing relationship when set against China's trade links with its more immediate neighbours: its trade with ASEAN in 2012, for example, was a staggering $\$ 400$ billion and is expected to reach $\$ 1$ trillion a year by 2020 [17], far outweighing the trade with West Asia.

Iran and Iraq are not far behind their GCC counterparts: $56 \%$ of Iran's trade is now with China alone and $77 \%$ of its total exports in 2013 went to just four Asian countries: China, India, South Korea, and Japan. Crucially, the same four Asian countries met $50 \%$ of Iran's total imports. ${ }^{16}$ Until the 1990 s, it should be noted, it was the EU which dominated Iran's trade. In the case of Iraq, whose economy has been a victim of war and sanctions since the 1980s, $70 \%$ of its exports today go to the same four Asian countries and it receives one quarter of its imports from them. So, when compared with the rest of the region, it is clear that the oil-rich Persian Gulf subregion, the GCC as the most dynamic economies of the Arab world in particular, is in fact the most 'Asianized' part of the MENA subsystem. They do all look Eastwards. Their success in building

\footnotetext{
$15 \mathrm{http} / / /$ vision.ae/en/articles/gec_asian_economic_ties_set_to_soar (accessed January 2015)

${ }^{16}$ Observatory of Economic Complexity, http://atlas.media.mit.edu/profile/country/irn/ (accessed January 2015). Equally significantly, non-oil trade between Iran and China reached \$13 billion in 2013.
} 
closer links with South and East Asia, however, underlines the uneven nature of MENA Asianization and the limits of pan-Asian development.

Europe's energy-saving drive since late twentieth century and America's extraordinary success in extracting oil through fracking in the twenty first have led to noticeable reductions in the Euroatlantic bloc's oil imports from the Middle East, which has coincided with dramatic rises in demand from the emerging Asian economies. The growing dependence of Asian economies on Middle East oil has changed the balance of petroleum demand in the twenty-first century. What is evident is that the oil exporters have begun responding to the changing global energy market and are focusing their energies on South and East Asia, and in this, the 'security of their future oil and gas exports will become more and more dependent on their energy relations with China and other East Asian countries' ([24], p. 15).

Given the historical weight of Western involvement in West Asia, however, it is unlikely that the West will part from its interests in this strategic and hydrocarbon-rich part of the world anytime soon, and is also as unlikely that the region's West-leaning countries will cease their close security ties with the USA and its European allies. But, arguably, the contours of the regional powers' relationship with the West have changed, and in one critical instance, at least the attention of the Middle East has shifted Eastwards, and that is in terms of their economic development. As was put by the secretary general of Saudi Arabia's Committee for International Trade, Omar Bahlaiwa, 'We are in a Catholic marriage with America [divorce is unthinkable]. But we are also Muslims - we can have more than one wife'. ${ }^{17}$

There is, however, a growing depth and intensity to intra-Asian economic relations, where investment and also trade are increasingly inter-Asian, and West Asian countries are major contributors to this transformational process as suppliers of energy, relatively large markets, and of course capital. The energy-rich countries of the Middle East certainly grease the wheels of Asianization. Beyond energy, the key components of these relationships are oil-related and infrastructural investments, non-petroleum trade, security ties (where China and increasingly India are partners of choice), defence partnerships, and cultural and educational ties [10]. So, the building of new refineries in East Asia is being financed by the oil-rich states, and East Asian corporations in turn are winning major oil exploration projects and infrastructural, construction, transport, and even power-generating contracts in West Asia: Japanese and South Korean corporations have led in these fields since the 1970s and remain strong (as with South Korea's \$22 billion award in 2009 to build four nuclear power plants in the UAE), but China is now a major player in development projects in the Middle East. Starting with the construction of Tehran's underground system in the 1990s, Chinese firms have stolen the march on their Asian competitors by winning contracts for the building of railroads in the GCC countries as well as pushing ahead with Israel's strategically important Eilat-Ashdod rail freight link project which could compete with the Suez Canal as an alternative transit route between the Mediterranean and the Indian Ocean. It is similarly involved in developing infrastructural, assembly plants and energy-related projects in North Africa, particularly in Egypt and Algeria. China's efforts to build west-east energy infrastructural networks, pipelines from Russia and West and Central

\footnotetext{
${ }^{17}$ Hassan M. Fattah, Hu's Saudi Visit Signals a Change in the Gulf, International Herald Tribune, 24 April 2004.
} 
Asia to China, are also helping to consolidate pan-Asian strategic links and places China at the heart of Eurasian economic networks. The Chinese-sponsored road, maritime, and rail 'silk roads' are promising to reweave the cloth of Asian trade routes, and other East Asian countries stand to gain from such massive initiatives.

Beyond the linkages which drive the geographical edges of Asia closer together, it is also clear that there is uneven 'Easternization' and the data gathered suggests that the Persian Gulf subregion has emerged as the most Asianized part of the MENA subsystem [18]. The relationships which have emerged are a product of modern industrialization and a consequence of modern trade patterns being dictated by the energy-hungry economies of India and East Asia. In this, the Persian Gulf greases the wheels of global industry which is increasingly located in Asia. A critical reading of the concentration of economic power in the East also will suggest that power is unevenly divided across Asia and highly contested.

\section{Convergence of Interests vs Convenience of Relations}

It was suggested earlier that the increasingly strategic relationship between the edges of Asia is a product of loose regionalization being forged by the changes in the hydrocarbon market (the strategic export commodities of West Asia and the strategic import commodities of South and East Asia). Loose regionalization is nevertheless generating important pan-Asian networks and, as already noted, increasing investment, infrastructural, and energy tie-ups. But, do the Middle East oil exporters have a plan B for declines in Asian growth rates affecting their hydrocarbon imports? Do they really have options in a world where European and American demand remains flat and they need to compete with Russia and others for market share? The simple answer is no, and for that reason, the oil producers are keen to broaden the base of their partnerships in Asia and diversify them away from oil. In this strategy, Asian countries are willing partners, and to facilitate these pan-regional relations, several formal fora have also been established, such as the Japan-GCC Free Trade Agreement, the China-Arab States Cooperation Forum, the Indo-GCC Business Forum, the GCC-China Economic Forum, and the Kuala Lumpur-based GCC-ASEAN Economic Centre. These fora help to manage the flow of traffic between Asian regions and the Middle East and also advance the emerging networks.

Despite these networks and increases in the frequency of diplomatic exchanges, travel, flights, and passenger numbers, and Asian leaders' talk of building strategic partnerships with their Middle East counterparts, in reality, what we have deepens economic and commercial links without politics. Clearly, the South and East Asian states' strategy is designed to avoid the dangers of being embroiled in the MENA region's intractable security and political problems, to avoid the securitized American route of engagement with the region, but as their embrace strengthens and Asian powers appear to rise on the ladder of global prominence, so the Middle East regimes increasingly look at their 'strategic' partners in Asia to act in consort with their growing 'understanding'. In practice, the South and East Asian side of the equation would rather avoid facing in public or private the tough choices in advancing the Arab-Israeli peace process, confronting Jihadists, committing resource to tackling security problems of various regimes, or helping create a nuclear weapons-free zone which would require 
Israel to declare its weapons programme and Iran to abandon many aspects of its, but the growing Asian interdependencies mean that Asian powers can no longer avoid the crises of the MENA region or continue to expect the USA to address them. The strategic vulnerabilities are huge and are getting more complex.

\section{Strategic Vulnerabilities}

Complex interdependence is the prism through which the thickening of Middle EastEast/South Asia links has been analysed here, but the same also provides the basis for a better understanding of the enhanced dangers of cross-regional insecurity contamination. Strategically speaking, the Middle East marks the geopolitical middle of the transition from West to East and as such is a significant space for the remaining West and the emerging East. East Asia's energy dependence on West Asia is perhaps the most profound aspect of the former's strategic vulnerabilities. As we saw in 1979, when Iranian oil exports left Japan short, in 1990s when the loss of Iraqi and Kuwaiti oil exports affected the Asian importers and in 2003 when the US invasion of Iraq took Iraq out of the oil market for nearly a decade, the Asian economies are incredibly vulnerable to the domestic changes and regional tensions arising in the Middle East. All the Asian hydrocarbon consumers also face another problem, arising from their exposure to Western/US interventions in the Middle East. Despite its apparent weakness in dealing with the region's multiple crises effectively, the USA remains the dominant external actor in the MENA region whose actions do have a direct impact on the energy security of Asian importers. In 2003, US military action severed Asian access to Iraq's oil, and in 2011, US-led sanctions on Iran raised the premium on their commercial dealings with Iran, and while Japan and South Korea-under US pressure - suffered by loosening their ties, China and India did the opposite and banked on Iran's economic isolation to extract easier access to its oil as well as its market.

Added to the dangers of turmoil from West Asia disrupting Asian convergence is the less than benign strategic landscape of East Asia itself [3]. Crises in Northeast Asia, over North Korea's belligerence towards the South and Japan and Japanese-Chinese border disputes and naval presence, Taiwan, all have the potential to erupt into open conflict which would certainly suck into the theatre the USA but would also become a hazard for West Asian countries which have profitable trade links with several of these countries and no political influence to note. The dangers of losing trade (and income) will be magnified to a real security crisis if the USA were to intervene on behalf of its East Asian allies and seek the isolation of China.

In East Asia, the fear of an assertive China, 'peaceful rise with teeth', has generated complex responses - from Southeast Asian countries bandwagoning with the USA to the creation of an India-Japan-led Asian 'democracy axis' to tighten the Tokyo-New Delhi-Seoul triangle for the purpose of balancing against China's southward and westward. Also, it should be noted, the policies of Asia's giants themselves towards their West Asian counterparts have broad implications. Thus, China's close ties with Pakistan, including close military ties and extending to giving Chinese navy maritime access to ports on the Arabian Sea, have resulted in India drawing closer to Iran since the early 2000s. This would be consistent with the analysis that if India regards 'China's support for Pakistan, as well as its encroachment into the Indian Ocean... as 
part of a coherent strategy to encircle India and confine its influence to South Asia' ([19], p. 116), then it would react by forging strategic links with the neighbouring regional powers. It has done so with great success in Southeast Asia but has also begun to do so in West Asia. So, following President Khatami's visit in January 2003, India pushed to create a military bond with Iran, despite Tehran's close military links with China, and agreed to provide training for the Iranian armed forces, maintain and upgrade Iran's Russian-supplied armour (its fleet of MiG-29 fighters, T-72 main battle tanks, and armoured carriers), conduct joint naval exercises, and generally assist in the maintenance of Iran's armed forces, for which it claimed the strategic prize of access to Iranian territory. Iran's agreement, as part of this accord, to allow Indian forces to train on its soil was perceived in Pakistan as Tehran in effect consenting to Indian encirclement of Pakistan. ${ }^{18}$ In Israel, itself a military partner of India, the accord was criticized for giving Iran (the 'epicentre of international terrorism' in their view) access to new military technologies which it would use against Israel's interests. Though this was never the intention of the Iran-India military accord, it is easy to see how it can be misperceived and misunderstood by competing powers. Israeli nervousness of course alerted the USA to the potential dangers of Iran-India military cooperation which resulted in American pressure on New Delhi to limit its ties with Iran in return for a closer partnership with the USA. So, it is self-evident how such relationships can leave the West Asian region open to new types of pressure, arising from the power dynamics of South Asia and also the dynamics of relations between India and China as continental Asian powers of this century. India and China compete for influence in West Asian countries, but as this is a dialectical process, so their competition echoes in the region in which both have a direct strategic interest. But in pursuit of their energy interests, they also find themselves exposed to competitive forces at play in the Middle East.

For the MENA countries, which have grown weary of (Western) intervention and illadvised policies in the region, Asian countries appear to provide safe havens of diplomacy. Asian giants do not assume to intervene or pass judgement on the internal affairs of their MENA counterparts, and for a country like China, which purports to uphold the doctrine of non-intervention, this position can be an advantageous diplomatic pawn. But for the MENA countries which have become dependent on Western (US) protection, or for those who are attempting to balance against the USA (Iran, Syria), non-intervention can very easily translate into non-interest. China and India, as Asia's political powers, will have to tread carefully in this respect. The easy passage of UN-imposed intrusive sanctions on Iran has shown that Beijing may not have the firmness to veto what could have been interpreted as Western interference in the internal affairs of a close economic partner; India's vote at the UN in support of sanctions brought stinging criticism from Tehran; China's eleventh hour intervention in support of Muammar Qaddafi in the dying days of his regime was badly received across the Arab world; and China's opposition to the isolation of the violent Assad regime in Syria has appeared to much of the Arab world as China not be the best judge of regional relations.

\footnotetext{
${ }_{18}$ Asia Program (2004). The Strategic Partnership between India and Iran. Asia Program Special Report, No. 120, April. Washington, DC: Woodrow Wilson International Center for Scholars.
} 
In the context of strategic interdependence, one fear is that the chaos of the MENA subsystem could potentially spill over into Asian theatres and thus threaten the national security of several Asian countries at once. Of particular concern in countries with Muslim minorities, namely China, India, the Philippines, is the radicalization of their Muslim populations, the evidence for which is to be found in the periodic terror campaigns besetting these countries. Equally worrying for South and East Asia is the rise of militancy in the Southeast Asian Muslim countries, a growth in sympathies for local Salafi Islamist groups, or worse still a tide of support for Al-Qaeda or ISIS in their midst. Developments in the Middle East can act as a conveyor belt for radicalization in Southeast Asia. When it comes to building alliances with West Asia, the constellation of relations is so competitive that building strategic/security ties becomes truly hazardous. Thus, both India and China have faced grave difficulties in adjusting their policies to the highly competitive nature of Iranian-Saudi Arabian relations, and in favouring one, each had had to make concessions to the other. Even less fortunate have been Japan and South Korea who have found it impossible to pick a winner in the ongoing power struggle between Tehran and Riyadh, and have had to opt for the Saudi side so as not to incur the wrath of the USA.

\section{Conclusion}

What has been argued is that shift in the balance of economic power, alongside a structural shift in the global energy market, has been driving the Asianization of the Middle East and, as an energy-led process, will also augment the deepening of panAsian relationships to increasingly include Central Asia. But Asianization is not synonymous with de-Westernization. The USA and its European allies have many other interests in the Middle East besides energy, and it is therefore unlikely to sever their long-standing relationships with their Arab allies, or indeed Israel. However, as Israel itself becomes a player in the energy market, aiming to become an exporter in the next few years, so its security calculations will likely change too to reflect its new status. Israel has chosen to stay close to the USA for security protection, but as an oil producer, it will be tempted by the markets of Asia and may opt to cultivate widening its security partnerships with such oil- and gas-consuming countries as China, India, Taiwan, and South Korea in anticipation of serving as a new source of hydrocarbons for these Asian consumers.

Finally, the much discussed US pivot towards East Asia is first and foremost contingent on a successful effort to stabilize the Middle East, which ironically can only happen with the US active engagement. America's allies - in Europe and in the Middle East - will therefore not accept a unilateral American disengagement that would leave them without external support. They will likely do what they can to keep the Western bloc's presence strong in what is essentially the European Union's backyard. So, while West Asia's history is increasingly being written with Asian hands, it is still those powers that shaped the MENA subsystem which still determine what is being written. Asianization may be, but not, pan-Asian regionalism yet. 
Open Access This article is distributed under the terms of the Creative Commons Attribution 4.0 International License (http://creativecommons.org/licenses/by/4.0/), which permits unrestricted use, distribution, and reproduction in any medium, provided you give appropriate credit to the original author(s) and the source, provide a link to the Creative Commons license, and indicate if changes were made.

\section{References}

1. Acharya, A. (2002). Regionalism and the Emerging World Order: Sovereignty, Autonomy, Identity. In S. Breslin, C. W. Hughes, N. Phillips and B. Rosamond (eds) New Regionalisms in the Global Political Economy (pp. 20-32). London: Routledge.

2. Al-Tamimi, N. M. (2014).China-Saudi Arabia Relations, 1990-2012: Marriage of Convenience or Strategic Alliance?. New York, NY: Routledge.

3. Bin Huwaidin, M. (2002).China's Relations with Arabia and the Gulf 1949-1999. London: RoutledgeCurzon.

4. Bromley, S. (1994). Rethinking Middle East Politics. Cambridge: Polity Press.

5. Campbell, I. (2013). India's Role and Interests in Central Asia. London: Saferworld.

6. Carter, H. and Ehteshami, A. (eds) (2004).The Middle East's Relations with Asia and Russia. London: RoutledgeCurzon.

7. Cerny, P. G. (1995). Globalization and the Changing Logic of Collective Action. International Organization, 49(4), 595-625.

8. Cleveland, W. L. (2000). A History of the Middle East. Boulder, CO: Westview Press.

9. Economist Intelligence Unit (2014) GCC Trade and Investment Flows. London: EIU.

10. Ehteshami, A. (2013). Dynamics of Change in the Persian Gulf: Political Economy, War and Revolution. New York, NY: Routledge.

11. Ehteshami, A. and Miyagi, Y. (ds) (2015).The Emerging Middle East-East Asia Nexus. New York, NY: Routledge.

12. Fawcett, L. and Hurrell, A. (eds) (1995) Regionalism in World Politics: Regional Organization and International Order. Oxford, Oxford University Press.

13. Fawn, R. (2009). Globalising the Regional, Regionalising the Global. Cambridge: Cambridge University Press.

14. Flores-Marcias, G. A. and Kreps, S. E. (2013). The Foreign Policy Consequences of Trade: China's Commercial Relations with Africa and Latin America, 1992-2006. The Journal of Politics, 75(2).

15. Gulf Research Center (2006).Dynamic Alliances: Strengthening Ties between the GCC and Asia. Dubai: Gulf Research Center.

16. Hurrell, A. (1995). Regionalism in Theoretical Perspective. In L. Fawcett and A. Hurrell (eds) Regionalism in World Politics: Regional Organization and International Order (pp. 37-73). Oxford, Oxford University Press.

17. Janardhan, N. (2014). GCC-Asia Ties and Collective Security. Jeddah: Gulf Research Center.

18. Kemp, G. (2012).The East Moves West: India, China and Asia's Growing Presence in the Middle East. Washington, D.C.: Brookings Institution Press.

19. Ladwig, W. C. III (2010). India and the Balance of Power in the Asia-Pacific. Joint Force Quarterly, 57(2), 111-119.

20. Nye, J. (1971).Peace in Parts: Integration and Conflict in Regional Organizations. Boston, MA: Little, Brown and co.

21. Niblock, T. and Malik, M. (eds) (2013).Asia-Gulf Economic Relations in the $21^{\text {st }}$ Century: The Local to Global Transformation. Berlin: Gerlach Press.

22. Scott, A. J. (1998).Regions and the World Economy: The Coming Shape of Global Production, Competition, and Political Order. Oxford: Oxford University Press.

23. Sklair, L. (1991). Sociology of the Global System. London: Harvester Wheatsheaf.

24. Yang, G. (2014). World Energy Markets and China's Relations with West Asia. Journal of Middle Eastern and Islamic Studies (in Asia), 8(3), 1-24. 